\title{
Oral vitamin B12 for patients suspected of subtle cobalamin deficiency: a multicentre pragmatic randomised controlled trial
}

\author{
Bernard Favrat ${ }^{1 *}{ }^{*}$, Paul Vaucher ${ }^{1,2+}$, Lilli Herzig ${ }^{2}$, Bernard Burnand ${ }^{3}$, Giuseppa Ali ${ }^{1}$, Olivier Boulat ${ }^{4}$, \\ Thomas Bischoff ${ }^{2}$, François Verdon ${ }^{2}$
}

\begin{abstract}
Background: Evidence regarding the effectiveness of oral vitamin B12 in patients with serum vitamin B12 levels between 125-200 pM/l is lacking. We compared the effectiveness of one-month oral vitamin B12 supplementation in patients with a subtle vitamin B12 deficiency to that of a placebo.

Methods: This multicentre (13 general practices, two nursing homes, and one primary care center in western Switzerland), parallel, randomised, controlled, closed-label, observer-blind trial included 50 patients with serum vitamin B12 levels between 125-200 pM/I who were randomized to receive either oral vitamin B12 (1000 $\mu \mathrm{g}$ daily, $N=26)$ or placebo ( $N=24)$ for four weeks. The institution's pharmacist used simple randomisation to generate a table and allocate treatments. The primary outcome was the change in serum methylmalonic acid (MMA) levels after one month of treatment. Secondary outcomes were changes in total homocysteine and serum vitamin B12 levels. Blood samples were centralised for analysis and adherence to treatment was verified by an electronic device (MEMS; Aardex Europe, Switzerland). Trial registration: ISRCTN 22063938.
\end{abstract}

Results: Baseline characteristics and adherence to treatment were similar in both groups. After one month, one patient in the placebo group was lost to follow-up. Data were evaluated by intention-to-treat analysis. One month of vitamin B12 treatment $(\mathrm{N}=26)$ lowered serum MMA levels by $0.13 \mu \mathrm{mol} / \mathrm{I}(95 \% \mathrm{Cl} 0.06-0.19)$ more than the change observed in the placebo group $(\mathrm{N}=23)$. The number of patients needed to treat to detect a metabolic response in MMA after one month was 2.6 (95\% Cl 1.7-6.4). A significant change was observed for the B12 serum level, but not for the homocysteine level, hematocrit, or mean corpuscular volume. After three months without active treatment (at four months), significant differences in MMA levels were no longer detected.

Conclusions: Oral vitamin B12 treatment normalised the metabolic markers of vitamin B12 deficiency. However, a one-month daily treatment with $1000 \mu \mathrm{g}$ oral vitamin B12 was not sufficient to normalise the deficiency markers for four months, and treatment had no effect on haematological signs of B12 deficiency.

\section{Background}

Vitamin B12 deficiency (less than $150 \mathrm{pM} / \mathrm{l}$ ) is common in elderly people, with the reported prevalence ranging from $15 \%$ to $20 \%[1,2]$. Most patients show no evidence of megaloblastic anaemia; however, these patients are still at risk for neurological abnormalities [3]. Furthermore, vitamin B12 deficiency leads to hyperhomocysteinemia,

\footnotetext{
* Correspondence: bernard.favrat@hospvd.ch

† Contributed equally

'Department of Ambulatory Care and Community Medicine, University of

Lausanne, Bugnon 44, CH-1011 Lausanne, Switzerland

Full list of author information is available at the end of the article
}

an independent risk factor for ischemic heart disease [4] and dementia [5]. Comparisons between patients with known complications and "normal" control patients [6] have produced several definitions of cobalamin deficiency. Over the past 15 years, the definition of vitamin B12 deficiency has included determination of two metabolites due to their favourable sensitivities and specificities: serum methylmalonic acid (MMA) and homocysteine (Hcys) $[7,8]$. Over the past few decades, a number of publications and two randomised controlled trials have demonstrated that oral B12 is as efficacious as

\section{Biomed Central}

(c) 2011 Favrat et al; licensee BioMed Central Ltd. This is an Open Access article distributed under the terms of the Creative Commons Attribution License (http://creativecommons.org/licenses/by/2.0), which permits unrestricted use, distribution, and reproduction in any medium, provided the original work is properly cited. 
intramuscular injection, especially for normalising metabolic markers of cobalamin deficiency [9-13], and is also cost-effective [14].

Nevertheless, there is a lack of randomised placebocontrolled trials to validate the use of oral vitamin B12 therapy [15]. Furthermore, few randomised placebocontrolled trials have evaluated the biological impact of oral therapy $(1000 \mu \mathrm{g} / \mathrm{d})$ in general practice for borderline serum vitamin B12 concentrations (125-200 pM/l) among patients without pernicious anaemia [16,17]. Our objective was to evaluate the efficacy of oral cobalamin in reducing MMA levels in patients suspected of vitamin B12 deficiency but with borderline vitamin B12 concentrations. This type of study is important for helping to determine whether the MMA level "indicates or predicts a clinical condition in need of treatment" [18].

\section{Methods}

A pragmatic $[19,20]$, placebo-controlled, randomised controlled trial with a four-month follow-up period was conducted by 16 general practitioners in the western part of Switzerland between October 2002 and September 2004. The study protocol was approved by the ethics review committee for clinical research of the Department of Internal Medicine, University of Lausanne, and was registered in the Current Controlled Trial Database (ISRCTN 22063938).

\section{Participants}

Physicians enrolled patients from private practices (13 general practitioners), an academic primary care centre (counted as one general practitioner), and nursing homes (two general practitioners). Patients in whom physicians suspected B12 deficiency based on clinical parameters were asked to participate. Patients who were suspected of having cobalamin deficiency met at least one of the following inclusion criteria: history of cobalamin deficiency, red cell macrocytosis ( $>99 \mathrm{fl}$ ), or neurological or psychiatric symptoms (or both) defined as having three or more positive responses to the symptoms described in Table 1.

Consenting patients with serum vitamin B12 levels equal to or greater than $125 \mathrm{pM} / \mathrm{l}$ but equal to or less than $200 \mathrm{pM} / \mathrm{l}$ were included. Exclusion criteria included folate deficiency, renal insufficiency, and folate or vitamin B12 treatment during the preceding six months. For ethical reasons, patients with vitamin B12 levels less than $125 \mathrm{pM} / \mathrm{l}$ after one month received oral vitamin B12 supplementation for one month. Written informed consent was obtained from all patients before screening for vitamin B12 deficiency. Details of refusal, exclusion, dropouts, and missing data were collected when available. Blood samples and baseline values were collected before treatment allocation. All blood samples were centralised and analysed using a single analysis method.

\section{Treatment, randomisation, blinding, and adherence to therapy}

Participants received either $1000 \mu \mathrm{g}$ oral vitamin B12 (cobalamin) or placebo daily for four weeks. An independent pharmacist delivered active or placebo pills according to a prior, simple computer-generated randomisation list. The active and placebo pills were similar in appearance and taste and were given in a similar container. Patients, caregivers, investigators, and the statistician were blinded to treatment until the end of the trial. Each drug package was coded with a unique number according to the randomisation schedule, then sent to the relevant practice. The codes were held by the pharmacists and remained unbroken until the analysis was completed. Patients were asked not to take any other vitamin supplements, and the treating physician verified this at the one- and four-month follow-up visits.

\section{Table 1 Reasons for patient eligibility reported by physicians $\left(N=49^{*}\right)$}

\begin{tabular}{|c|c|c|}
\hline Symptoms & Oral B12 (N = 26) N(\%) & Placebo $\left(\mathrm{N}=23^{*}\right) \mathrm{N}(\%)$ \\
\hline $\begin{array}{l}\text { "Do you have a pins and needles feeling in your feet?" or "Do you have a compelling } \\
\text { urge to move your legs in the evening or at night?" }\end{array}$ & $10(38 \%)$ & $7(30 \%)$ \\
\hline $\begin{array}{l}\text { "Have you recently felt unsteady when walking for reasons other than your rheumatism } \\
\text { or after having an accident?" }\end{array}$ & $5(19 \%)$ & $3(13 \%)$ \\
\hline $\begin{array}{l}\text { "During the past month have you often been bothered by feeling down, depressed, } \\
\text { or hopeless?" and "During the last month, have you often been bothered by having little interest } \\
\text { or pleasure in doing things? [41] }\end{array}$ & $7(27 \%)$ & $8(35 \%)$ \\
\hline "Did you feel that you were losing your memory or has someone mentioned this to you lately?" & $5(19 \%)$ & $4(17 \%)$ \\
\hline "Has your character changed lately or has someone mentioned this to you?" & $2(8 \%)$ & $3(13 \%)$ \\
\hline $\begin{array}{l}\text { "Has it been more difficult for you to perform your usual activities, } \\
\text { such as reading a book, watching TV, writing, paying bills, doing your housework, etc.?" }\end{array}$ & $5(19 \%)$ & $6(26 \%)$ \\
\hline Anemia detected (blood formula) & $4(15 \%)$ & $6(26 \%)$ \\
\hline Macrocystosis (blood formula) & $4(15 \%)$ & $5(21 \%)$ \\
\hline
\end{tabular}

* One questionnaire was not returned by the physician. 


\section{Outcomes}

The principle outcome was the relative difference in serum MMA levels at baseline and after one month of treatment. Responders were defined as those participants exhibiting more intra-individual variation in MMA (a decrease in the serum MMA level greater than $0.076 \mu \mathrm{mol} / \mathrm{l})$ than that caused by random variation [21]. Secondary outcomes were changes in serum vitamin B12 levels, total Hcys levels, and clinical improvement based on symptoms and physical signs at the oneand four-month follow-up visits. Changes in MMA levels measured at baseline and after four months were also determined. The relative improvement toward the population mean value and the number of patients needed to treat (NNT) were reported as secondary outcomes for MMA. Haematological improvement was measured for mean corpuscular volume and hematocrit. Cognitive changes were assed using the Mini Mental State Examination (scale ranging from 30 to 0 ).

\section{Measurements and laboratory methods}

Medical visits and blood sampling were performed by physicians at baseline and after one and four months. Participants participated in a structured interview to record socio-demographic variables, medical history, complaints, the reason why the physician suspected vitamin B12 deficiency, medication, importance of neurological or psychiatric signs, and state of health.

Blood samples were drawn by standard antecubital venipuncture from patients who were not fasting. Two separate tubes were collected; all tubes were centralised for analysis in a single laboratory. Samples were centrifuged and serum concentrations of MMA, Hcys, creatinine, vitamin B12, and folate were measured. Renal insufficiency was defined as a serum creatinine level greater than $97 \mu \mathrm{mol} / \mathrm{l}$, folate insufficiency as a serum value below $7 \mathrm{nmol} / \mathrm{l}$, and red cell macrocytosis as a value greater than $99 \mathrm{fl}$. Haematological parameters were measured by an automated analyser (Sysmex XE2100; Sysmex corporation, Hyogo, Japan). Serum creatinine levels were measured by the Jaffé kinetic method at $37^{\circ} \mathrm{C}$ (Modular ANALYTICS system; Roche Diagnostics, Basel, Switzerland). Serum vitamin B12 and folate levels were measured by a quantitative radioimmunoassay using purified intrinsic factor and purified folate-binding protein. MMA levels in serum were determined by gas chromatography and mass spectrometry with isotopic dilution. Analytical performance was assessed by internal and external quality controls (ERNDIM; http://www. erndimqa.nl/). Typical coefficients of variation were less than $3.8 \%$ at $0.39 \mu \mathrm{mol} / \mathrm{l}(\mathrm{N}=55)$ and less than $3.7 \%$ at $1.75 \mu \mathrm{mol} / \mathrm{l}(\mathrm{N}=61)$. Total Hcys levels in serum were quantified by high performance liquid chromatography with fluorimetric detection [22]. Typical coefficients of variation were less than $5.2 \%$ at $5.5 \mu \mathrm{mol} / \mathrm{l}(\mathrm{N}=120)$ and less than $3.3 \%$ at $16.4 \mu \mathrm{mol} / \mathrm{l}(\mathrm{N}=143)$. Adherence to treatment was verified by an electronic device (MEMS; Aardex Europe, Switzerland) that recorded the date and time of every opening of the pill container. Unused pills were also counted. Adherence was quantified by calculating the percentage of days that the pill container was opened once.

\section{Statistical methods}

Our study was powered to detect a mean decrease in MMA values of $0.2 \mu \mathrm{mol} / 1$ in the treatment group as compared with $0.05 \mu \mathrm{mol} / \mathrm{l}$ in the placebo group. Expecting a standard deviation of $0.15 \mu \mathrm{mol} / \mathrm{l}$ with the significance level set at $\mathrm{p}<0.05$ and power set at 0.8 , the estimated sample size was 16 participants in each group. Based on previous data [23], we estimated that the proportion of responders (as determined by a change in MMA) would be $10 \%$ in the placebo group and at least $50 \%$ in the intervention group, necessitating the inclusion of 25 patients in each group.

We performed the principal analysis according to intention to treat (all patients remained in their initially assigned arm). The planned measure of magnitude of effects was absolute change difference from baseline between the treatment and placebo arms. This difference was determined by computing the least square means of differences with linear regression, adjusting for baseline value. Robust standard error [24] was used to take heteroscedasticity into consideration. To control for the observed lack of homogeneity of variance for different baseline values, we also computed the improvement from baseline in proportion to what would have been expected had the values become normal (relative improvement). This secondary measure of intervention effect was the relative improvement difference between arms ( $\mathrm{R} \Delta \%)$. Based on previously published information, we considered the healthy population's mean MMA value to be $0.17 \mu \mathrm{mol} / \mathrm{l}$ [25], the mean Hcys value to be $10.2 \mu \mathrm{mol} / 1$ [25], and the mean vitamin B12 value to be $375 \mathrm{pM} / \mathrm{l}$ [26]. If the values changed to exceed the mean population value, the measure of effect was limited to 1.0. If no improvement was detected at follow-up, or if the baseline values were already normal, the measure of effect was considered null. Student's $t$-test was used to evaluate the significance of the observed difference between those patients receiving B12 and those receiving placebo. No measures were taken to control the overall type I error rate because outcomes were expected to be highly correlated to each another. The NNT was calculated considering dropouts and missing data as non-responders. We set the alpha level to 0.05 and calculated 95\% confidence intervals (CIs). All statistical analyses were performed using Stata 10.0 (StataCorp LP, College Station, TX, USA). 


\section{Results}

Vitamin B12 deficiency was suspected in 81 patients. Three patients refused to participate $(4 \%)$ without providing reasons, 14 (17\%) had B12 serum values less than $125 \mathrm{pM} / \mathrm{l}$ and were given B12 treatment, and 14 (17\%) had serum values greater that $200 \mathrm{pM} / \mathrm{l}$ and were excluded. The 50 remaining patients were randomly assigned (Figure 1$)$ to the placebo arm $(\mathrm{N}=24)$ or the experimental arm $(\mathrm{N}=26)$. The symptoms that most frequently made the physician suspect B12 deficiency were paraesthesia and depression (Table 1). Age, sex, and other characteristics were similar between the groups (Table 2). Doses and proportion of days with correct medication were 27.4 intakes and $93.5 \%$ of days for the oral B12 group and 28.4 intakes and $94.4 \%$ of days for the placebo group. Seven patients (one from the treatment group) had vitamin B12 levels less than 125 $\mathrm{pM} / \mathrm{l}$ at one month and received oral vitamin B12 supplementation for one extra month. These patients were included in the intention to treat analysis. One questionnaire was not completed by the physician. Transport inconvenience prevented 18/145 blood samples (from 13 patients) from being analysed for metabolites. Six of 50 electronic devices used to measure treatment compliance were not returned; thus, adherence data were missing for these patients. We observed no relevant side effects of treatment during the four-month follow-up period. Two adverse events were reported, both in the intervention group. One patient was hospitalised for psychiatric reasons and one was hospitalised to receive a blood transfusion. Physicians considered both of these events unrelated to vitamin B12 administration.

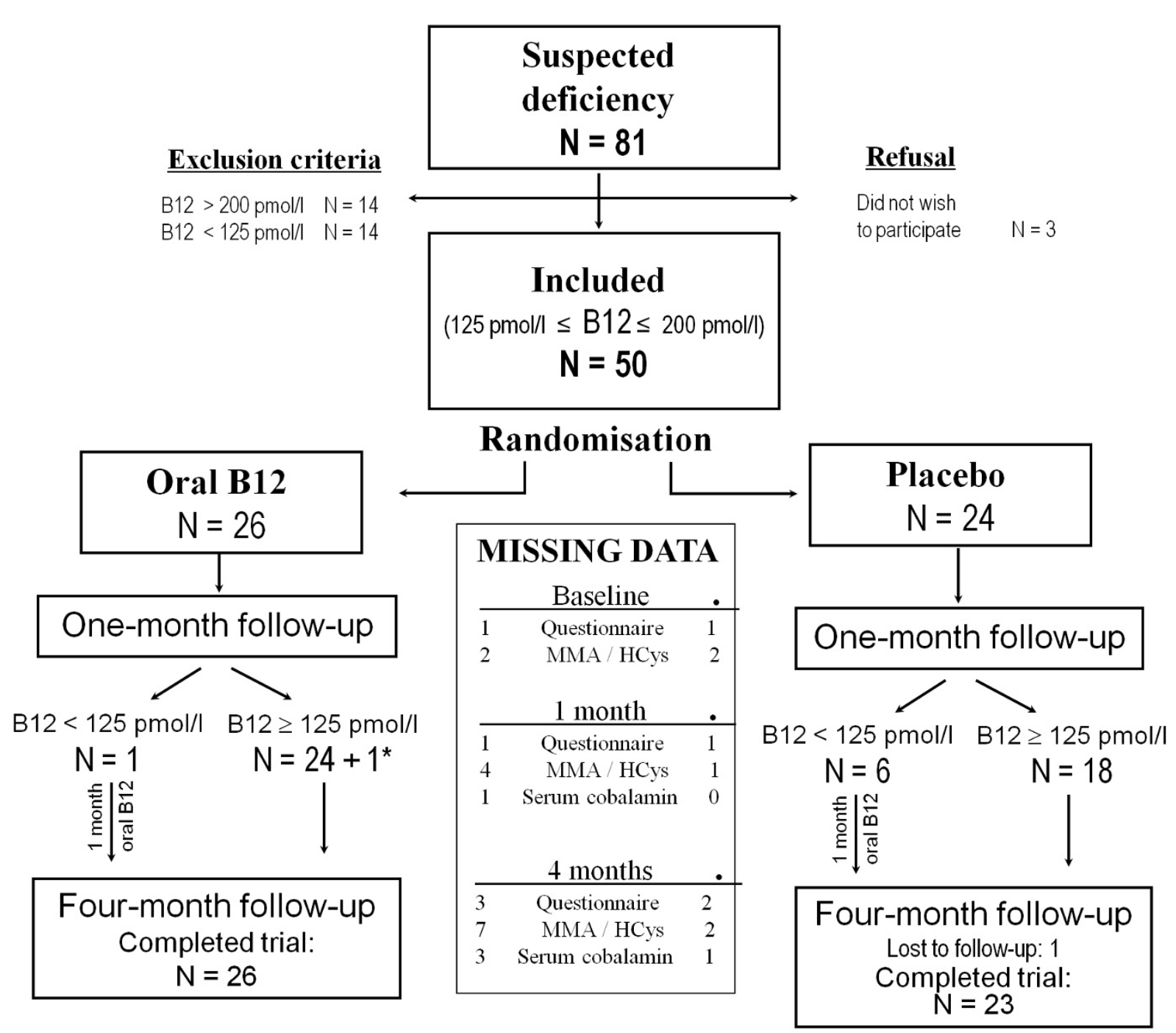

Figure 1 Flow chart of the study design. * B12 concentration was not available for one patient who was assumed not to be deficient. Hcys: homocysteine, MMA: methylmalonic acid. 
Table 2 Baseline characteristics of study participants

\begin{tabular}{|c|c|c|}
\hline & Oral B12 ( $N=26)$ & Placebo $(\mathrm{N}=24)$ \\
\hline Gender (Female) & $14(53.8 \%)$ & $13(54.2 \%)$ \\
\hline \multicolumn{3}{|l|}{$n(\%)$} \\
\hline \multicolumn{3}{|l|}{ Age } \\
\hline Mean (SD) & 69.6 yrs $(\mathrm{SD}=18.8)$ & 68.6 yrs $(S D=18.5)$ \\
\hline Median (range) & 76 yrs $(31-91)$ & 75 yrs $(18-88)$ \\
\hline \multicolumn{3}{|l|}{ Serum B12 } \\
\hline Mean (SD) & $164 \mathrm{pM} / \mathrm{l}(\mathrm{SD}=24)$ & $154 \mathrm{pM} / \mathrm{l}(\mathrm{SD}=20)$ \\
\hline Median (range) & 164 pM/l (127 - 203) & $150 \mathrm{pM} / \mathrm{l}(126-191)$ \\
\hline \multicolumn{3}{|l|}{ Serum MMA } \\
\hline Mean (SD) & $0.43 \mu \mathrm{mol} / \mathrm{l}(\mathrm{SD}=0.25)^{*}$ & $0.41 \mu \mathrm{mol} / \mathrm{I}(\mathrm{SD}=0.24)^{*}$ \\
\hline Median (range) & $0.32 \mu \mathrm{mol} / \mathrm{l}(0.19-1.1)$ & $0.31 \mu \mathrm{mol} / \mathrm{l}(0.15-0.92)$ \\
\hline \multicolumn{3}{|c|}{$M M A \geq 0.26 \mu \mathrm{mol} / \mathrm{l}$} \\
\hline$n(\%)$ & $18(83.3 \%)^{*}$ & $16(72.7 \%)^{*}$ \\
\hline \multicolumn{3}{|l|}{ Serum HCys } \\
\hline Mean (SD) & $18.3 \mu \mathrm{mol} / \mathrm{I}(\mathrm{SD}=6.6)^{*}$ & $15.0 \mu \mathrm{mol} / \mathrm{l}(\mathrm{SD}=5.3)^{*}$ \\
\hline Median (range) & $18.1 \mu \mathrm{mol} / \mathrm{l}(9.8-31.5)$ & $14.3 \mu \mathrm{mol} / \mathrm{l}(7.5-27.1)$ \\
\hline \multicolumn{3}{|l|}{ Hematocrit } \\
\hline Mean (SD) & $40.3 \%(\mathrm{SD}=4.2)^{\dagger}$ & $39.5 \%(S D=4.6)$ \\
\hline Median (range) & $39.5 \%(32-46)$ & $40 \%(27-47)$ \\
\hline \multicolumn{3}{|l|}{$\begin{array}{l}\text { Mean corpuscular } \\
\text { volume }\end{array}$} \\
\hline Mean (SD) & $91.2 \mathrm{fl}(\mathrm{SD}=9.2)^{\dagger}$ & $92.6 \mathrm{fl}(\mathrm{SD}=5.1)$ \\
\hline Median (range) & $90 \mathrm{fl}(63-100)$ & $92 \mathrm{fl}(81-111)$ \\
\hline \multicolumn{3}{|l|}{ Serum creatinine } \\
\hline Mean (SD) & $96.4 \mu \mathrm{mol} / \mathrm{l}(\mathrm{SD}=27.9)$ & $89.0 \mu \mathrm{mol} / \mathrm{I}(\mathrm{SD}=27.2)$ \\
\hline Median (range) & $86 \mu \mathrm{mol} / \mathrm{l}(60-160)$ & $89 \mu \mathrm{mol} / \mathrm{l}(37-137)$ \\
\hline \multicolumn{3}{|l|}{ Serum folic acid } \\
\hline Mean (SD) & $16.6 \mathrm{nmol} / \mathrm{l}(\mathrm{SD}=9.1)$ & $19.2 \mathrm{nmol} / \mathrm{l}(\mathrm{SD}=10.9)$ \\
\hline Median (range) & $16.2 \mathrm{nmol} / \mathrm{l}(5.6-45.3)$ & $14 \mathrm{nmol} / \mathrm{l}(5.4-33)$ \\
\hline
\end{tabular}

Hcys = homocysteine, MMA = methylmalonic acid, SD = standard deviation. * Transport inconvenient generated missing total at random data; samples were not analysed for 2 patients in the oral B12 group and for 2 patients in the placebo group.

+ One physician did not report results from the blood formula onto the case report form. Data were unvailable for one patient in the oral B12 group.

At baseline, $21.7 \%$ of patients had MMA levels that were considered normal (less than $0.26 \mu \mathrm{mol} / \mathrm{l}$ ). Serum concentrations of metabolites at baseline, one month, and four months appear in Figure 2. A significant treatment effect was observed on surrogate values of serum vitamin B12 after both one and four months, and on MMA values at one month (Table 3). Per-protocol analysis also confirmed the absence of a difference in mean MMA concentrations between the placebo and treatment groups at four months $(-0.02 \mu \mathrm{mol} / \mathrm{l} ; 95 \% \mathrm{CI}-0.16$ to $0.13 ; \mathrm{p}=0.832)$. We also measured the relative improvement effect toward the healthy population's mean value (Table 4). At one month, patients undergoing vitamin B12 treatment decreased their mean deficit by $48.7 \%$ (95\% CI 29.0 to 68.3 ) over placebo. Finally, the NNT for improving MMA serum concentration at one month was 2.6 patients ( $95 \%$ CI 1.7 to 9.4).

\section{Discussion}

This study has demonstrated that in primary care patients with nonspecific symptoms and borderline serum vitamin B12 levels, serum MMA levels were corrected more often in patients receiving one month of oral cobalamin therapy than in patients receiving one month of placebo. However, the benefit to the MMA level disappeared after three additional months without cobalamin therapy.

Although treatment has been deemed necessary regardless of laboratory results for patients with signs of severe cobalamin deficiency $[27,28]$, in general practice one might question the impact of treatment for patients with nonspecific symptoms suspected to be related to cobalamin deficiency. The definition of cobalamin deficiency remains imprecise; a definition based only on clinical symptoms lacks specificity up to advanced stages, except in cases of pernicious anaemia. Therefore, a serum vitamin B12 level below $125 \mu \mathrm{mol} / \mathrm{l}$ cannot be the sole criterion for defining cobalamin deficiency. No clear cut-off values have been defined, and publications have variously asserted that there are "grey areas" below $295 \mathrm{pM} / 1$ [29], $200 \mathrm{pM} / 1$ [30], or $250 \mathrm{pM} / \mathrm{l}$ [27].

The metabolic markers MMA and Hcys show promise as markers for improving the diagnosis of cobalamin deficiency $[7,8,31]$. Our randomised controlled trial showed an improvement in MMA levels and a nonsignificant fall in Hcys following oral B12 supplementation for one month (Table 3). For MMA, our results corroborate observations from three other pertinent trials $[17,32]$ and one equivalent trial comparing oral to parenteral administration [12]. However, our study is the first to follow patients after cessation of treatment. Our findings suggest that one month of treatment is not enough to maintain MMA serum concentrations above borderline deficit. Furthermore, one month of treatment may not be sufficient to affect Hcys levels, as other studies have demonstrated improvement after treatment periods of three months [33]. The specificity of Hcys is considered low, which may also explain the low response of Hcys levels to vitamin B12 therapy [27]. Hcys levels are also influenced by lifestyle habits (coffee, alcohol, and smoking), renal function, genetic abnormalities, and folate deficiency.

In the primary care setting, the importance of subtle cobalamin deficiency and its related clinical impact remain under debate. Increased concentrations of MMA metabolites in patients without anaemia define subtle cobalamin deficiency [29]. The prognostic and clinical significances of this state are not clear [34]. Neuropathy, anaemia, and cognitive impairment are possible $[15,35,36]$, and some observational studies have demonstrated a clinical benefit from treatment, including oral therapy $[15,35]$. However, Solomon found patients with 


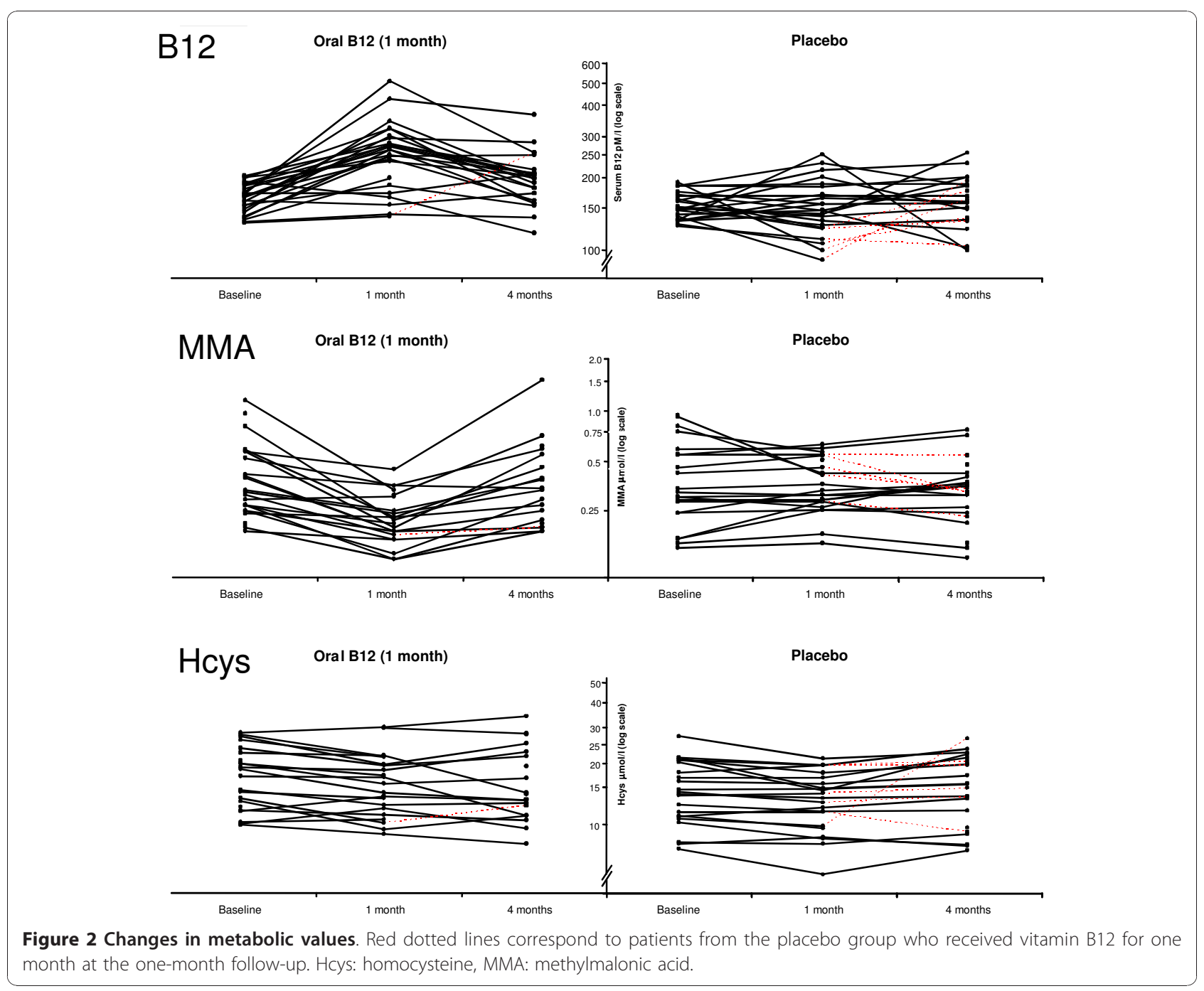

Table 3 Different outcomes in the oral B12 treatment group and the placebo group after one and four months

\begin{tabular}{|c|c|c|c|c|c|c|}
\hline \multirow[b]{2}{*}{ Biological marker } & \multicolumn{2}{|l|}{ Oral B12 } & \multicolumn{2}{|l|}{ Placebo } & \multicolumn{2}{|c|}{$\begin{array}{l}\text { Impovement from baseline between oral B12 and } \\
\text { placebo* }\end{array}$} \\
\hline & $\begin{array}{l}1 \text { month Mean } \\
\text { (SD); N }\end{array}$ & $\begin{array}{l}4 \text { months Mean } \\
\text { (SD); N }\end{array}$ & $\begin{array}{l}1 \text { month Mean } \\
(\mathrm{SD}) ; \mathrm{N}\end{array}$ & $\begin{array}{l}4 \text { months Mean } \\
\text { (SD); N }\end{array}$ & $\begin{array}{l}1 \text { month }^{*} \Delta(\mathrm{Cl} 195 \% ; \\
\text { p-value })\end{array}$ & $\begin{array}{l}4 \text { months* } \triangle(\mathrm{Cl} 95 \% ; \\
\text { p-value) }\end{array}$ \\
\hline MMA $(\mu \mathrm{mol} / \mathrm{l})$ & $0.23(0.08) ; 22$ & $0.41(0.30) ; 19$ & $0.37(0.14) ; 23$ & $0.35(0.16) ; 22$ & $\begin{array}{l}-0.13(\mathrm{Cl} 195 \%-0.19 \text { to }-0.06 ; \\
p<0.001)\end{array}$ & $\begin{array}{l}0.03(\mathrm{Cl} 195 \%-0.12 \text { to } 0.17 \\
p=0.686)\end{array}$ \\
\hline $\begin{array}{l}\text { Serum cobalamin } \\
(\mathrm{pM} / \mathrm{l})\end{array}$ & $263.4(89.8) ; 25$ & $202.6(56.3) ; 23$ & $154.5(41.1) ; 24$ & 162.9 (39.8); 23 & $\begin{array}{l}101.6(C 195 \% 60.1 \text { to } 143.2 ; \\
p<0.001)\end{array}$ & $\begin{array}{l}35.0(\mathrm{Cl} 195 \% 6.4 \text { to } 63.5 \\
\mathrm{p}=0.018)\end{array}$ \\
\hline Hcys ( $\mu \mathrm{mol} / \mathrm{l})$ & $16.5(6.1) ; 22$ & $17.1(7.5) ; 19$ & $13.9(4.3) ; 23$ & $15.6(5.8) ; 22$ & $\begin{array}{l}0.04(C 195 \%-1.2 \text { to } 1.3 \\
p=0.950)\end{array}$ & $\begin{array}{l}-1.0(\mathrm{Cl} 195 \%-4.0 \text { to } 2.0 \\
\mathrm{p}=0.502)\end{array}$ \\
\hline $\begin{array}{l}\text { Hematocrite }(\% \text { red } \\
\text { cells) }\end{array}$ & $39.6(4.1) ; 26$ & $40.1(4.0) ; 26$ & $39.7(4.6) ; 24$ & $39.4(4.6) ; 22$ & $\begin{array}{l}-0.4(\mathrm{Cl} 195 \%-1.7 \text { to } 0.8 \\
\mathrm{p}=0.502)\end{array}$ & $\begin{array}{l}0.5(\mathrm{Cl} \mid 95 \%-1.0 \text { to } 2.1 \\
p=0.475)\end{array}$ \\
\hline MCV (fl) & 89.8 (6.9); 26 & $89.0(7.0) ; 26$ & $92.8(7.0) ; 24$ & $92.6(7.6) ; 22$ & $\begin{array}{l}-0.4(\mathrm{Cl} 195 \%-2.2 \text { to } 1.4 \\
p=0.674)\end{array}$ & $\begin{array}{l}-0.1(C 195 \%-2.3 \text { to } 2.2 \\
p=0.950)\end{array}$ \\
\hline MMSE (score 0-30) & - & $27.8(2.3) ; 26$ & - & $28.1(2.2) ; 21$ & - & $\begin{array}{l}-0.4(C \mid 95 \%-1.3 \text { to } 0.6 \\
p=0.432)\end{array}$ \\
\hline
\end{tabular}

* Least square means were computed using linear regression with robust standard error to take heteroscedasticity into account. Each value at 1 or 4 months was introduced separately as the dependent variable, with group allocation and baseline value as independent variables. Interpretation of these magnitudes is nevertheless restricted. Variance is not constant across baseline values (heteroscedasticity). Effects are more important for patients with initial higher levels of deficiency. Hcys = homocysteine, MMA = methylmalonic acid, MMSE= Mini Mental State Examination. 
Table 4 Differences in relative improvement* effects toward the healthy population's mean value between the oral B12 treatment and placebo group (RA\%) at 1 and 4 months

\begin{tabular}{|c|c|c|}
\hline \multirow[b]{2}{*}{ Biological marker } & \multicolumn{2}{|c|}{ Relative improvement effect towards healthy population's mean value } \\
\hline & 1 month R $\Delta \%$ (CI95\%; p-value) & 4 months R $\Delta \%$ (Cl95\%; p-value) \\
\hline MMA $(\mu \mathrm{mol} / \mathrm{l})$ Reduction & $48.7 \%(C 195 \%$ 29.0:68.3; $p<0.001)$ & $0.2 \%(C 195 \%-17.8: 18.3 ; p=0.979)$ \\
\hline Serum cobalamin $(\mathrm{pM} / \mathrm{l})$ Increase & $26.9 \%(C 195 \% 13.9: 39.8 ; p<0.001)$ & $14.1 \%(C \mid 95 \%-3.1: 31.3 ; p=0.105)$ \\
\hline Hcys ( $\mu \mathrm{mol} / \mathrm{l})$ Reduction & $1.8 \%(C 195 \%-16.4: 20.0 ; p=0.844)$ & $6.7 \%(C 195 \%-11.3: 24.7 ; p=0.455)$ \\
\hline
\end{tabular}

* Improvement from baseline compared to what would have been expected had the values become normal (MMA = $0.17 \mu \mathrm{mol} / \mathrm{l}$, vitamin B12 = $375 \mathrm{pM} / \mathrm{I}$, and Hcys $=10.2 \mu \mathrm{mol} / \mathrm{l})$.

clinical signs of cobalamin deficiency but normal levels of metabolic markers [34]. In a randomised controlled trial in community-dwelling subjects, Lewerin found that four months of oral $0.5 \mathrm{mg}$ vitamin B12 in combination with folic acid and vitamin B6 normalised serum MMA and Hcys levels, but failed to improve movement and cognitive performance [37]. Hvas also reported limited clinical improvement following administration of vitamin B12 to patients with elevated MMA (0.4-2 $\mu \mathrm{mol} / \mathrm{l})$ levels [18,34,38]. However, controversy continues to surround the question of whether vitamin B12 supplements affect cognition [39]. In our study, one month of oral vitamin B12 significantly increased serum cobalamin levels, but the effect did not persist after three more months without supplementation. These results are unexpected, given the liver storage capacity for vitamin B12 and the quantity of B12 administered during this study, and the effectiveness of intermittent treatment remains uncertain. Surrogates alone may not provide sufficient evidence to assume clinical benefits of vitamin B12 supplementation. Further studies are required to assess the effects on clinical outcomes.

One limitation of our study lies in defining the population for which our results are applicable. Further randomised trials are still necessary to evaluate the prophylactic effect of oral B12 for preventing neurological manifestations [40]. Mishandling of blood samples resulted in the loss of some data. These unexpected events and other missing data were not included in our initial sample size estimation, limiting the power of our study. Most missing data were missing completely at random, our results were therefore not biased, and only the power of the study was diminished. Finally, the inclusion of essentially non-anaemic patients who are less likely to respond to vitamin B12 treatment may affect our ability to generalise our results to an anaemic, cobalamin-deficient population.

\section{Conclusion}

Although oral B12 therapy evoked an important metabolic response, this response did not persist for an additional three months following cessation of therapy, causing us to question whether extending oral vitamin B12 treatment beyond one month would have a significant effect on the clinical manifestations of cobalamin deficiency. Whether correcting abnormal metabolic markers in hopes of improving clinical symptoms in patients with suspected borderline cobalamin deficiency is a clinically auspicious strategy remains under debate.

\section{List of abbreviations}

Hcys: homocysteine; MMA: methylmalonic acid; NNT: number needed to treat; SD: standard deviation; $\mathrm{R} \triangle \%$ : relative reduction difference towards the healthy population's mean value

\section{Acknowledgements}

We thank the general practitioners who served as local investigators, without whom this study would not have been possible. We thank the institution's pharmacy for preparing the randomisation list, sending the appropriate material to each physician, and for managing the electronic devices measuring compliance. We thank Françoise Secretan, research nurse, for her meticulous work as data manager. We also thank Streuli Pharma AG, Uznach, Switzerland, for preparing pills (placebo and active) and providing them to us for this study.

\section{Author details}

${ }^{1}$ Department of Ambulatory Care and Community Medicine, University of Lausanne, Bugnon 44, CH-1011 Lausanne, Switzerland. ${ }^{2}$ Institute of General Medicine, University of Lausanne, Bugnon 44, CH-1011 Lausanne, Switzerland. ${ }^{3}$ Institute of Social and Preventive Medicine, University of Lausanne, Bugnon 17, CH-1005 Lausanne, Switzerland. 'Laboratory of Clinical Chemistry, Hospices-CHUV, Bugnon 46, CH-1011 Lausanne, Switzerland.

\section{Authors' contributions}

$B F, F V, L H, B B, G A$, and TB designed the study. PV, BF, and FV analysed and interpreted the data. BF and PV drafted the manuscript. FV, LH, BB, GA, and TB revised and corrected the draft. All authors read and approved the final manuscript.

\section{Competing interests}

$B F, P V, L H, B B, G A, O B, T B$, and FV all declare the absence of any financial or non-financial competing interests.

Received: 16 July 2010 Accepted: 13 January 2011

Published: 13 January 2011

\section{References}

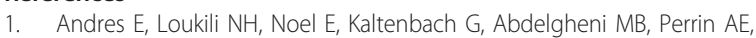
Noblet-Dick M, Maloisel F, Schlienger JL, Blickle JF: Vitamin B12 (cobalamin) deficiency in elderly patients. CMAJ 2004, 171(3):251-259.

2. Pennypacker LC, Allen RH, Kelly JP, Matthews LM, Grigsby J, Kaye K, Lindenbaum J, Stabler SP: High prevalence of cobalamin deficiency in elderly outpatients. JAmGeriatrSoC 1992, 40(12):1197-1204.

3. Lindenbaum J, Healton EB, Savage DG, Brust JC, Garrett TJ, Podell ER, Marcell PD, Stabler SP, Allen RH: Neuropsychiatric disorders caused by 
cobalamin deficiency in the absence of anemia or macrocytosis. NEnglJMed 1988, 318(26):1720-1728.

4. Nygard O, Nordrehaug JE, Refsum H, Ueland PM, Farstad M, Vollset SE: Plasma homocysteine levels and mortality in patients with coronary artery disease. NEnglJMed 1997, 337(4):230-236.

5. Seshadri S, Beiser A, Selhub J, Jacques PF, Rosenberg IH, D'Agostino RB, Wilson PW, Wolf PA: Plasma homocysteine as a risk factor for dementia and Alzheimer's disease. NEnglJMed 2002, 346(7):476-483.

6. Snow CF: Laboratory diagnosis of vitamin B12 and folate deficiency: a guide for the primary care physician. Arch/nternMed 1999, 159(12):1289-1298.

7. Lindenbaum J, Savage DG, Stabler SP, Allen RH: Diagnosis of cobalamin deficiency: II. Relative sensitivities of serum cobalamin, methylmalonic acid, and total homocysteine concentrations. AmJHematol 1990, 34(2):99-107.

8. Savage DG, Lindenbaum J, Stabler SP, Allen RH: Sensitivity of serum methylmalonic acid and total homocysteine determinations for diagnosing cobalamin and folate deficiencies. AmJMed 1994, 96(3):239-246.

9. Andres $E$, Perrin $A E$, Demangeat $C$, Kurtz JE, Vinzio $S$, Grunenberger $F$, Goichot B, Schlienger JL: The syndrome of food-cobalamin malabsorption revisited in a department of internal medicine. A monocentric cohort study of 80 patients. EurJInternMed 2003, 14(4):221-226.

10. Berlin $H$, Berlin R, Brante G: Oral treatment of pernicious anemia with high doses of vitamin B12 without intrinsic factor. Acta MedScand 1968, 184(4):247-258.

11. Bolaman Z, Kadikoylu G, Yukselen V, Yavasoglu I, Barutca S, Senturk T: Oral versus intramuscular cobalamin treatment in megaloblastic anemia: a single-center, prospective, randomized, open-label study. ClinTher 2003, 25(12):3124-3134.

12. Kuzminski AM, Del Giacco EJ, Allen RH, Stabler SP, Lindenbaum J: Effective treatment of cobalamin deficiency with oral cobalamin. Blood 1998, 92(4):1191-1198

13. Lederle FA: Oral cobalamin for pernicious anemia. Medicine's best kept secret? JAMA 1991, 265(1):94-95.

14. van WC, Austin P, Naylor CD: Vitamin B12 injections versus oral supplements. How much money could be saved by switching from injections to pills? CanFamPhysician 2001, 47:79-86.

15. Andres $E$, Noel $E$, Kaltenbach $G$ : Usefulness of oral vitamin B12 therapy in vitamin B12 deficiency related to food-cobalamin malabsorption: Short and long-term outcome. EurJInternMed 2005, 16(3):218.

16. Dhonukshe-Rutten RA, van Zutphen M, de Groot LC, Eussen SJ, Blom HJ, van Staveren WA: Effect of supplementation with cobalamin carried either by a milk product or a capsule in mildly cobalamin-deficient elderly Dutch persons. Am J Clin Nutr 2005, 82(3):568-574.

17. Eussen SJ, de Groot LC, Joosten LW, Bloo RJ, Clarke R, Ueland PM, Schneede J, Blom HJ, Hoefnagels WH, van Staveren WA: Effect of oral vitamin B-12 with or without folic acid on cognitive function in older people with mild vitamin B-12 deficiency: a randomized, placebocontrolled trial. Am J Clin Nutr 2006, 84(2):361-370.

18. Hvas AM, Ellegaard J, Nexo E: Vitamin B12 treatment normalizes metabolic markers but has limited clinical effect: a randomized placebocontrolled study. ClinChem 2001, 47(8):1396-1404.

19. Roland M, Torgerson DJ: What are pragmatic trials? BMJ 1998, 316(7127):285

20. Godwin M, Ruhland L, Casson I, MacDonald S, Delva D, Birtwhistle R, Lam M, Seguin R: Pragmatic controlled clinical trials in primary care: the struggle between external and internal validity. BMC Medical Research Methodology 2003, 3(1):28.

21. Rasmussen K, Moller J, Ostergaard K, Kristensen M, Jensen J: Methylmalonic acid concentrations in serum of normal subjects: biological variability and effect of oral L-isoleucine loads before and after intramuscular administration of cobalamin. Clin Chem 1990, 36(7):1295-1299.

22. Vester B, Rasmussen K: High performance liquid chromatography method for rapid and accurate determination of homocysteine in plasma and serum. Eur J Clin Chem Clin Biochem 1991, 29(9):549-554.

23. Healton EB, Savage DG, Brust JC, Garrett TJ, Lindenbaum J: Neurologic aspects of cobalamin deficiency. Medicine (Baltimore) 1991, 70(4):229-245
24. Davidson R, Mackinnon J, Davidson J: Estimation and inference in econometrics New York: Oxford University Press; 1993.

25. Rasmussen K, Moller J, Lyngbak M, Pedersen A, Dybkjaer L: Age- and gender-specific reference intervals for total homocysteine and methylmalonic acid in plasma before and after vitamin supplementation. Clin Chem 1996, 42(4):630-636.

26. Lindenbaum J, Rosenberg $\mathrm{IH}$, Wilson PW, Stabler SP, Allen RH: Prevalence of cobalamin deficiency in the Framingham elderly population. Am J Clin Nutr 1994, 60:2-11.

27. Hvas AM, Nexo E: Diagnosis and treatment of vitamin B12 deficiency-an update. Haematologica 2006, 91(11):1506-1512.

28. Solomon LR: Cobalamin-responsive disorders in the ambulatory care setting: unreliability of cobalamin, methylmalonic acid, and homocysteine testing. Blood 2005, 105(3):978-985.

29. Carmel R: Subtle and atypical cobalamin deficiency states. AmJHematol 1990, 34(2):108-114.

30. Hvas AM, Nexo E: Holotranscobalamin as a predictor of vitamin B12 status. ClinChemLab Med 2003, 41(11):1489-1492.

31. Allen RH, Stabler SP, Savage DG, Lindenbaum J: Diagnosis of cobalamin deficiency I: usefulness of serum methylmalonic acid and total homocysteine concentrations. AmJHematol 1990, 34(2):90-98.

32. Deshmukh US, Joglekar CV, Lubree HG, Ramdas LV, Bhat DS, Naik SS, Hardikar PS, Raut DA, Konde TB, Wills AK, et al: Effect of physiological doses of oral vitamin B12 on plasma homocysteine: a randomized, placebocontrolled, double-blind trial in India. Eur J Clin Nutr 2010, 64(5):495-502.

33. Hoey L, Strain JJ, McNulty H: Studies of biomarker responses to intervention with vitamin B-12: a systematic review of randomized controlled trials. Am J Clin Nutr 2009, 89(6):1981S-1996S

34. Solomon LR: Disorders of cobalamin (vitamin B12) metabolism: emerging concepts in pathophysiology, diagnosis and treatment. Blood Rev 2007, 21(3):113-130.

35. Karnaze DS, Carmel R: Neurologic and evoked potential abnormalities in subtle cobalamin deficiency states, including deficiency without anemia and with normal absorption of free cobalamin. ArchNeurol 1990, 47(9):1008-1012.

36. Louwman MW, van DM, van DV, Thomas CM, Schneede J, Ueland PM, Refsum $H$, van Staveren WA: Signs of impaired cognitive function in adolescents with marginal cobalamin status. AmJClinNutr 2000, 72(3):762-769

37. Lewerin C, Matousek M, Steen G, Johansson B, Steen B, Nilsson-Ehle H: Significant correlations of plasma homocysteine and serum methylmalonic acid with movement and cognitive performance in elderly subjects but no improvement from short-term vitamin therapy: a placebo-controlled randomized study. AmJClinNutr 2005, 81(5):1155-1162.

38. Hvas AM, Juul S, Nexo E, Ellegaard J: Vitamin B-12 treatment has limited effect on health-related quality of life among individuals with elevated plasma methylmalonic acid: a randomized placebo-controlled study. J/nternMed 2003, 253(2):146-152.

39. Malouf R, Grimley Evans J: Folic acid with or without vitamin B12 for the prevention and treatment of healthy elderly and demented people. Cochrane Database Syst Rev 2008, 4: CD004514.

40. Andres $E$, Fothergill $H$, Mecili M: Efficacy of oral cobalamin (vitamin B12) therapy. Expert Opin Pharmacother 11(2):249-256.

41. Arroll B, Khin N, Kerse N: Screening for depression in primary care with two verbally asked questions: cross sectional study. BMJ 2003, 327(7424):1144-1146.

\section{Pre-publication history}

The pre-publication history for this paper can be accessed here: http://www.biomedcentral.com/1471-2296/12/2/prepub

doi:10.1186/1471-2296-12-2

Cite this article as: Favrat et al:: Oral vitamin B12 for patients suspected of subtle cobalamin deficiency: a multicentre pragmatic randomised controlled trial. BMC Family Practice 2011 12:2 